\title{
Alat Pengontrol Kekeruhan Air Kolam Dan Pemberi Makan Lele
}

\author{
Efrizon $^{1}$, Yulastri $^{2}$ Ifandi $^{3}$ \\ ${ }^{123}$ Jurusan Teknik Elektro Politeknik Negeri Padang \\ efrizon_s@yahoo.co.id \\ Kampus Politeknik Negeri Padang, Limau Manis Padang
}

\begin{abstract}
Many innovations that have been implemented by catfish breeders, where catfish are of a distinctive taste and make it a very popular thing in catfish lovers. Many farmers compete to get great seeds and are capable of producing good development and fast. This tool designer creates a tool that can be used by catfish farmer through a prototype in order to read and control the level of turbidity and automatic feeder. The level of turbidity is very important for catfish growth, where the level turbidity can band catfish growth. This tool is supported by supporting devices such as turbine sensors, ultrasonic sensors, RTC DS1307, servo motors and Atmega328 microcontrollers. The Turbinity sensor is used to measure the level of water that is going to go out from the fishpond. Furthermore, this research is also facilitated by an automatic feeder that will run according to the time that has been set by a farmer. When the feeding time is comming the servo motor will open the feed valve for a while based on food requirements time. Beside that the automatic feeder is also facilited by ultrasonic sensors that can be used for monitoring the availability of feeds when the feed in minimum the level will be active the buzzer or beeb.
\end{abstract}

Keywords: GE Turbidity Sensor, Ultrasonic Sensor, RTC, ATMega 328 microcontroller

\begin{abstract}
Abstrak-Banyak inovasi yang telah diterapkan oleh para peternak lele, yang mana lele adalah salah satu jenis ikan yang sangat digemari oleh orang-orang karena rasa yang khas, banyak para pembudidaya yang bersaing untuk mendapatkan bibit yang bagus dan bisa menghasilkan lele yang dapat berkembang dengan baik dan cepat. Pada alat ini perancang membuat alat yang berguna untuk para pembudidaya ikan lele, yang mana pada alat ini di rakit sebuah prototype untuk mengatur kekeruhan air kolam dan pemberi pakan lele. Dalam pertumbuhan ikan lele diperlukan tingkat kekeruhan air kolam yang mana apabila terlalu keruh dapat menyebabkan lambatnya pertumbuhan ikan. Perangkat yang digunakan pada alat ini yaitu sensor Turbinity, Sensor ultrasonic, RTC DS1307, Servo dan Mikrokontroler Atmega328. Sensor Turbinity berfungsi untuk mengukur tingkat kekeurahan air pada kolam lele. Pada saat air dikeluarkan ketinggian air akan dikontrol oleh sensor ultrasonic. Pada alat ini juga di terapkan alat pemberi makan yang terjadwal, yang mana untuk mendapatkan pertumbuhan ikan lele yang baik dan bagus diperlukan pengontrolan pemberian pakan. Pemberian pakan akan diatur mengunakan RTC, untuk pemberian makan akan terjadwal sesuai dengan waktu yang ditentukan oleh pembudidaya dan pada saat jam pakan telah datang maka motor servo akan membuka pintu pakan beberapa saat sesuai dengan perhitungan banyak pakan yg dibutuhkan. Dan pada pemberi pakan ikan juga diberikan sensor ultrasonic untuk mengatur ketersediaan pakan. Pada saat pakan dalam kondisi minimum maka buzzer akan aktif.
\end{abstract}

Kata kunci:Sensor GE Turbidity, Sensor Ultrasonic, RTC, Mikrokontroler ATMega 328

(C) 2018 Elektron Jurnal Ilmiah

\section{PENDAHULUAN}

Pesatnya teknologi saat ini khususnya dibidang elektronika sangat berkembang pesat dan berdampak kepada keadaan didunia sekarang seperti pembuatan alat-alat yang canggih yang bekerja secara otomatis dan memiliki ketelitian yang sangat tinggi pula. Di samping itu, teknilogi ini dapat digunakan utuk mencapai keefektifitasan dan keefesienan dalam tujuan tertentu. Pada saat ini ikan lele sangat banyak digunakan dalam dunia kuliner, bukan hanya karna rasa yang khas tetapi dalam budidayanya pun tidak terlalu sulit dalam mengembangkannya karena lele mempunyai daya tahan tubuh yang cukup bagus dan tidak memilih makanan yang akan ia makan. Namun untuk mendapatkan pertumbuhan lele yang baik dan bagus, sebaiknya diberi makanan yang memiliki protein yang tinggi. Seperti larva lalat atau belatung, dan juga rebusan perut ayam. Tetapi saat ini kebanyakan peternak lele memberi makanan berupa pellet. Pada pembudidayaan ikan lele diperlukan adanya pengontrol kekeruhan air, yang mana pada kolam lele air tidak boleh terlalu keruh, karena akan menurunkan tingkat pertumbuhan dan pegembanganbiakan lele tersebut. Oleh karena itu sangatlah penting adanya alat yang dapat mengontrol tingkat kekeruhan air pada kolam yang dapat bekerja sewaktu-waktu dan dapat mengontrol kekeruhan tersebut. Dan pada pembudidayaan ikan lele pemberian makan di anjurkan untuk tepat waktu, karena dapat membantu pertumbuhan lele semakin cepat. Dan oleh sebab itu dibutuhkan juga alat untuk pemberi makan ikan, agar dapat meringankan pekerjaan para 
pembudidaya. Oleh karena itu pada penelitian ini sensor kekeruhan air (Turbidity) yang berguna untuk dikembangkan sebuah alat yang dapat membantu para mengontrol kondisi kekeruhan air pada kolam lele. pembudidaya ikan lele. Alat Pengontrol Kekeruhan Air Ketika air kolam terlalu keruh, maka sensor Tubidity Kolam Dan Pemberi Makan Lele.

\section{METODE PENELITIAN}

Pada perancangan dan pembuatan sistem ini akan dijelaskan tentang cara kerja sistem yang terdapat dalam garis besar perancangan sistem dan diikuti dengan penjelasan tentang perangkat keras (hardware) yang terdiri dari beberapa bagian yang berfungsi untuk mengolah data. Kemudian diikuti dengan perancangan dan pembuatan perangkat lunak (software).

\section{A. Blok Diagram}

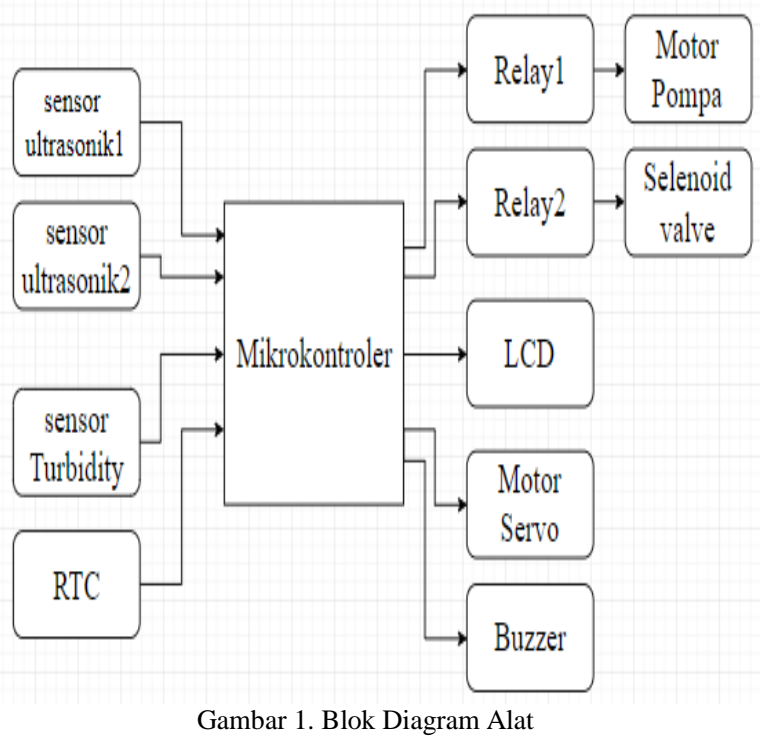

Berdasarkan blok diagram sistem pada Gambar 1 dapat dideskripsikan prinsip kerja alat yang dibuat pada tugas akhir ini. Alat pemberi makan ikan dan pendeteksi kekeruhan air pada kolam ikan yang bekerja secara otomatis setiap harinya. Pemberian pakan ikan secara otomatis berdasarkan waktu pada RTC yang telah disesuaikan dengan waktu yang sebenarnya. Pada program alat ini, waktu pemberian makan ditentukan 2 kali sehari yaitu pada pukul 07.00 WIB dan 17.00 WIB. Ketika telah mencapai waktu yang ditentukan servo akan membuka katup tempat pakan ikan dengan begitu pakan ikan akan turun. Servo akan aktif selama 3 detik dalam memberi makan ikan.Kondisi pakan pada tempat pakan ikan akan selalu dikontrol oleh sensor ultrasonik HCSR04. Ketika pakan ikan telah tinggal sedikit ( jarak sensor dengan pakan $\geq 5 \mathrm{~cm}$ ) maka sensor HC-SR04 akan memberi informasi pada mikrokontroler dan meneruskan informasi tersebut untuk mengaktifkan Buzzer. Bunyi Buzzer akan memberi tahu pemilik kolam ikan agar mengisi pakan ikan pada tempat penampung pakan ikan. Bunyi Buzzer tidak akan berhenti jika pakan ikan tidak kembali di isi. Pada alat ini juga dipasang akan menginformasikan ke mikrokontroler untuk mengaktifkan pompa air untuk mengeluarkan air kolam dan akan berhenti setelah ketinggian air mencapai batas ter rendah yang didapatkan dari sensor ultrasonic yang mana sensor ultrasonic digunakan unruk mengukur ketinggian air kolam lele, dan ketika sensor ultrasonic telah membaca ketinggian terendah air kolam pompa air akan mati dan akan mengaktifkan solenoid valve untuk memasukan air bersih dan mati ketika mencapai ketinggian yang di inginkan.

\section{B.Perancangan Perangkat Keras}

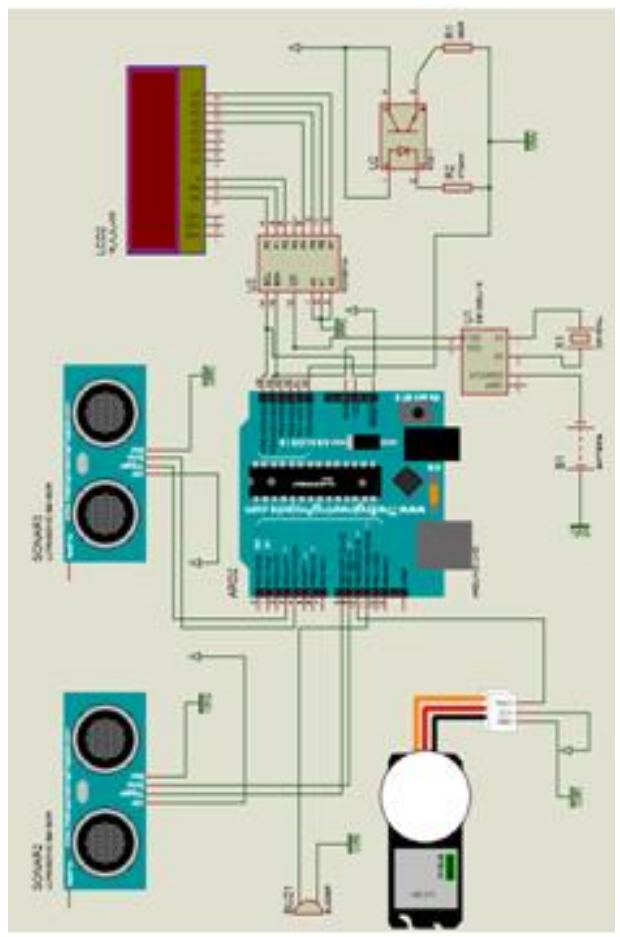

Gambar 2, Rangkaian Elektronika Alat

Perancangan perangkat keras pada alat ini ada beberapa bagian. Rangkaian Power Supply merupakan sumber tegangan DC untuk menyuplai tegangan semua sistem. RTC DS1307 berfungsi untuk menentukan waktu pemberian makan ikan setiap hari dan tepat pada waktunya. Pin RTC DS1307 yang akan digunakan hanya 4 buah yaitu SDA, SCL, Vcc dan Gnd. Pin SDA dan SCL dihubungkan pada pin analog A4 dan A5 pada mikrokontroler. Sensor HC-SR04 digunakan untuk mengontrol kondisi pakan ikan yang ada didalam tempat pakan ikan. Sensor HC-SR04 terdiri dari 4 pin yaitu Vcc, Trigger, Echo dan Gnd. Pin Trigger dihubungkan ke pin 7 dan pin Echo dihubungkan ke pin 8 pada mikrokontroler. Pada alat ini penulis mengunakan 2 sensor yaitu pada sensor 1 akan membaca jarak antara sensor dengan pakan ikan. Ketika jarak sensor dengan pakan besar sama dari $3 \mathrm{~cm}$ maka Buzzer akan berbunyi dan itu menginformasikan bahwa pakan ikan tinggal 
sedikit. Sesuai dengan table 1, dan sensor 2 akan kolam.ketika jarak sensor dengan air kolam >=15 maka membaca jarak antara sensor dengan ketinggian air relay 1 akan aktif dan ketika

ketinggian air kolam $<=5$ maka relay 1 akan mati relay

2 akan aktif sampai ketinggian air 15 relay 2 akan mati. Sesuai dengan tabel 2.

\begin{tabular}{cc}
\multicolumn{2}{c}{ Tabel 1. Kondisi makan } \\
\hline $\begin{array}{c}\text { Ketinggian } \\
\text { Makan }\end{array}$ & Buzzer \\
\hline 3 & On \\
\hline$>3$ & Off \\
\hline
\end{tabular}

\begin{tabular}{ccc}
\multicolumn{3}{c}{ Tabel 2. Kondisi ketinggian air } \\
\hline $\begin{array}{c}\text { ketinggian air } \\
\text { kolam } \\
(\mathrm{cm})\end{array}$ & relay 1 & relay 2 \\
\hline 5 & off & On \\
\hline 15 & 0n & Off \\
\hline
\end{tabular}

sensor GE Turbidity. Pin V dihubungkan ke sumber DC dengan tegangan $5 \mathrm{v}$, pin A dihubungkan ke arduino Port A0 untuk pembacaan keluaran sensor, dan pin G dihubungkan ke ground.Tabel kebenaran dari sensor GE Turbidity dapat di lihat pada tabel 3 .

Tabel 3. Tabel Kebenaran GE Turbidity

\begin{tabular}{ccc}
\hline Kondisi & $\begin{array}{c}\text { Pompa } \\
\text { (Pompa Untuk Air } \\
\text { keluar) }\end{array}$ & Solenoid \\
\hline Jernih & Mati & Tertutup \\
\hline Keruh & Hidup & Terbuka \\
\hline
\end{tabular}

Rangkaian arduino ini berfungsi untuk mempermudah menghubung input maupun output yang digunakan pada pin-pin mikrokontroler. Driver motor berfungsi untuk mengontrol arah putaran dan kecepatan motor DC. Driver motor ini akan dikendalikan menggunakan mikrokontroler, sehingga motor dapat diatur arah putaran dan kecepatan motor sesuai keinginan. Pada alat ini motor akan aktif memberi makan ikan ketika waktu pada RTC telah mencapai waktunya. Pin mikrokontroler yang digunakan untuk rangkaian driver motor ini adalah pin 5 dan 6. Motor servo merupakan motor DC yang dapat presisi dalam mengatur sudut penggunaannya. Dengan memanfaatkan karakteristik dari motor servo, pada alat ini motor servo dimanfaatkan sebagai pembuka katup penampung pakan ikan. Ketika telah sampai waktu pemberian makan ikan, motor servo akan membuka katup sebesar 20 derajat selama 3 menit. Pin mikrokontroler yang digunakan untuk pengaktifan motor servo adalah pin 9 dihubungkan ke pin input pada servo, Vcc ke pin Vcc servo dan GND pada GND pada servo. Rangakaian relay pada penelitian ini digunakan sebagai saklar elektronik yang akan mengaktifkan pompa air dan solenoid. Relay 1 digunakan untuk pengaktifan pompa air, relay 2 digunakan untuk buka tutup katup pada solenoid valve. Pin mikrokontroler yang digunakan untuk pengaktifan relay adalah pin 5 dan 6 . LCD digunakan untuk menampilkan waktu pada RTC dan data dari hasil pembacaan sensor pH. Rangkaian LCD ini menggunakan modul I2C yang berfungsi untuk mengurangi jumlah pin yang digunakan untuk I/O LCD. Buzzer merupakan suatu komponen yang dapat digunakan sebagai alat peringatan atau alarm. Buzzer berfungsi sebagai indikator untuk memberi tahu bahwa pakan ikan yang ada di dalam tempat pakan ikan tinggal sedikit. Pada saat itulah mikrokontroler memberikan perintah kepada Buzzer agar dapat berfungsi sesuai fungsinya. Buzzer terhubung pada pin 11.

\section{Perancangan Fisik Alat}

Berikut adalah perancangan fisik dari alat, pada gambar 3 dan 4 tampak samping dan belakang.

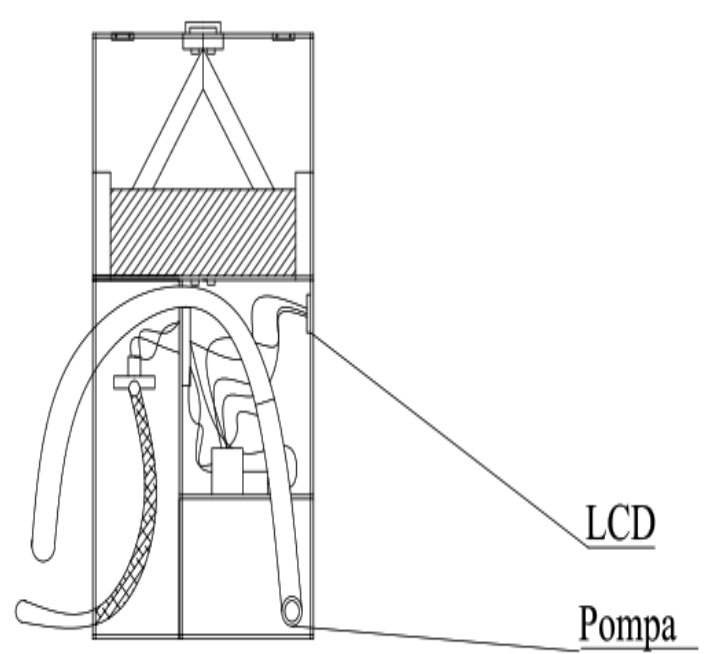

Gambar 3. Tampak samping

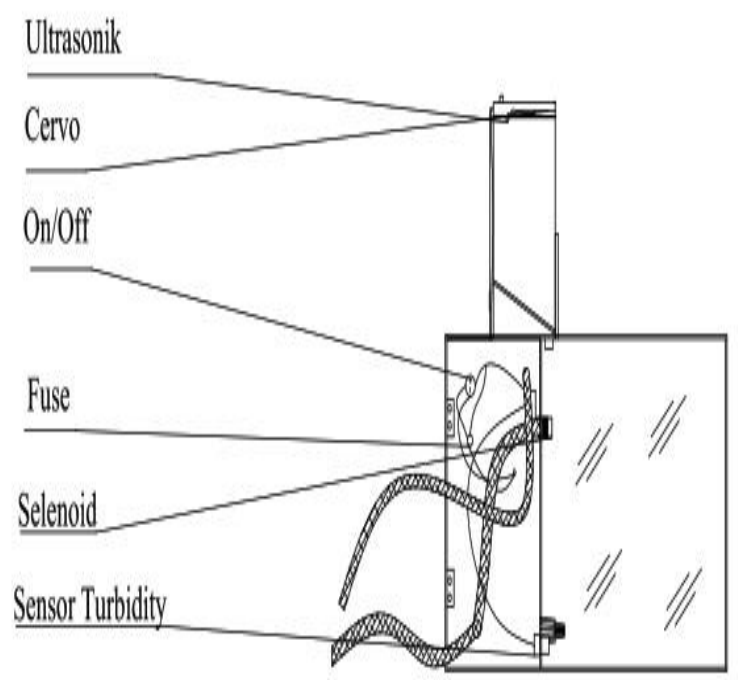

Gambar 4. Tampak belakang 


\section{Perancangan Perangkat Lunak (Software)}

Berikut adalah flow chart program dari alat

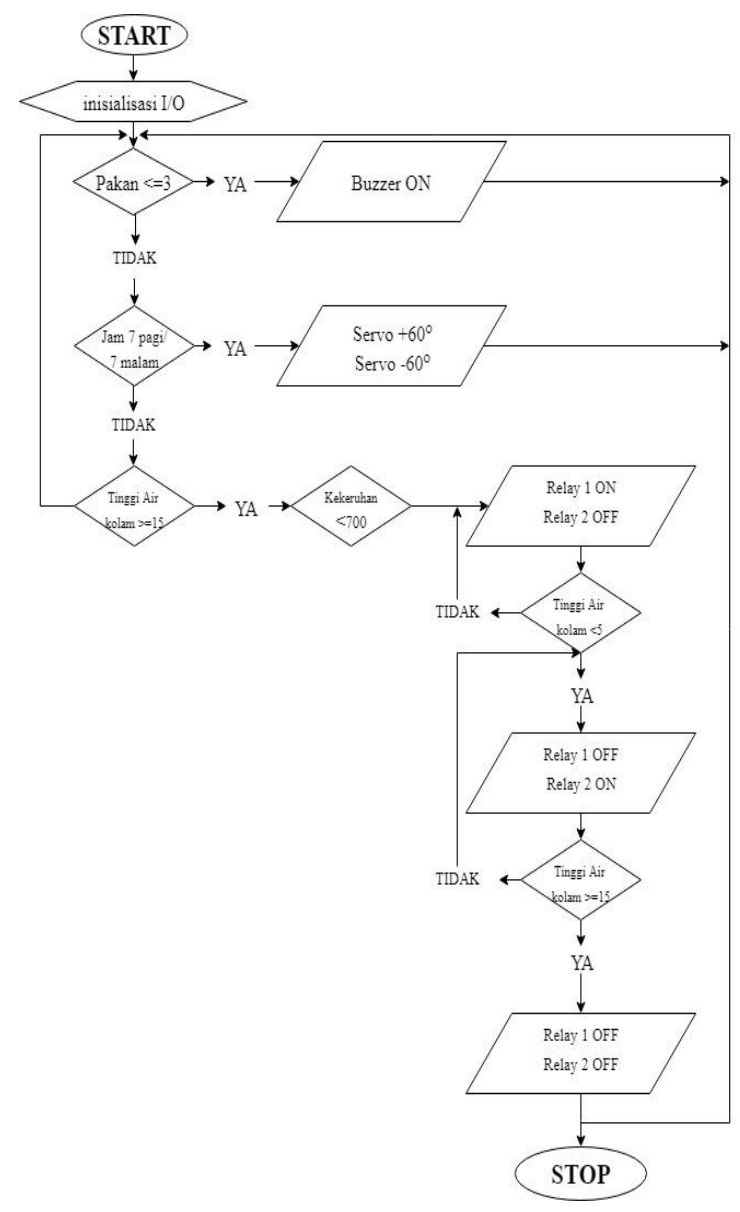

\section{Cara Pengoperasian Alat}

Cara pengoperasian alat ini sebagai berikut :

1. Isikan air ke dalam akuarium sampai batas maksimum.

2. Hubungkan slang air masuk ke kran.

3. Siapkan tempat air kotor.

4. Siapkan makanan sampai batas maksimum.

5. Hubungkan kabel supply ke sumber tegangan, tekan tombol ON untuk menghidupkan alat.

6. Alat akan mulai bekerja secara otomatis, jika air berada dalam kondisi keruh maka air akan diganti secara otomatis dan pemberian pakan terjadwal.

\section{HASIL DAN PEMBAHASAN}

Setelah pembuatan alat selesai dilakukan, maka tahap selanjutnya yaitu pengujian alat. Pada tahap pengujian alat ini bertujuan agar mengetahui apakah alat bekerja sesuai dengan harapan. Gambar 5 merupakan tampilan fisik alat yang telah dibuat.

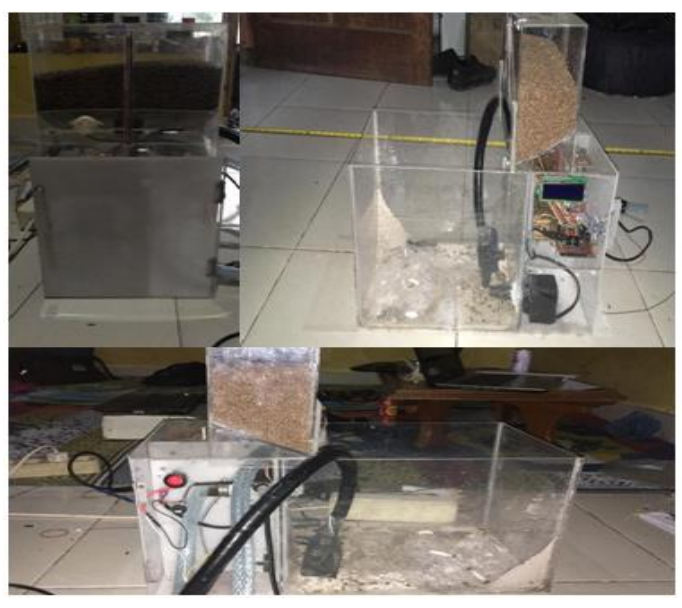

Gamabar 5. Tampilan fisik alat

\section{A.Pengujian dan Analisa Sensor GE Turbidity}

Dalam pengujian sensor ini digunakan untuk mengetahui berapa tegangan dan data ADC (analog digital convertion) yang akan dihasilkan dengan keadaan air yang telah ditentukan.Dalam pengujian sensor GE Turbidity ini penguji mengambil data awal dengan kondisi air jernih, Data ADC yang didapat adalah 960 dan tegangan output 4.7V. Pada pengujian dengan mengunakan abu gosok didapatkan data seperti table 4

Table 4. Hasil Pengukuran sensor GE Turbidity

\begin{tabular}{cccccc}
\hline NO & $\begin{array}{c}\text { Tingkat } \\
\text { Kekotoran air } \\
\text { (sendok) }\end{array}$ & $\begin{array}{c}\text { Tegangan } \\
\text { output } \\
(\mathrm{V})\end{array}$ & $\begin{array}{c}\text { Data } \\
\text { ADC }\end{array}$ & $\begin{array}{c}\text { Kondisi } \\
\text { air }\end{array}$ & NTU \\
\hline 1 & 1 & 4.65 & 940 & Bersih & 3 \\
\hline 2 & 2 & 4.63 & 910 & Bersih & 6 \\
\hline 3 & 3 & 4.60 & 880 & Bersih & 10 \\
\hline 4 & 4 & 4.57 & 856 & Bersih & 13 \\
\hline 5 & 5 & 4.55 & 810 & Bersih & 15 \\
\hline 6 & 6 & 4.53 & 766 & Bersih & 18 \\
\hline 7 & 7 & 4.51 & 724 & Bersih & 20 \\
\hline 8 & 8 & 4.49 & 693 & Kotor & 24 \\
\hline 9 & 9 & 4.47 & 659 & Kotor & 27 \\
\hline 10 & 10 & 4.46 & 616 & Kotor & 31 \\
\hline
\end{tabular}

Sensor ini bekerja dengan cara menghitung jumlah cahaya yang diterima oleh receiver. Pada saat kondisi air jernih receiver menerima cahaya dari transmitter sensor sehingga tegangan yang di keluarkan pada output sensor maksimal, ketika air ditambahkan 1 sendok abu gosok maka cahaya yang diterima oleh receiver akan berkurang karena cahaya terhalang oleh kotoran yang ada di dalam air sehingga tegangan yang dikeluarkan oleh pada output sensor akan berkurang, ketika air ditambahkan 3 sendok abu gosok maka air akan bertambah keruh sehingga cahaya yang diterima 
oleh receiver semakin berkurang dan tegangan yang dikeluarkan semakin kecil. Gambar 6 menampilkan grafik tegangan dengan satuan NTU.

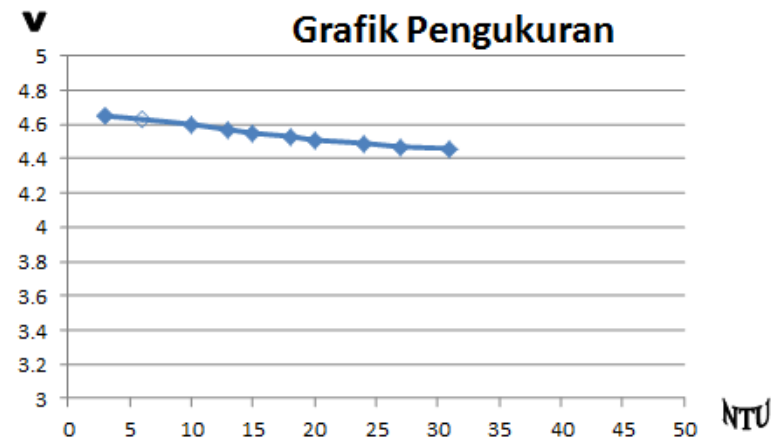

Gambar 6. Grafik tegangan output sensor dengan satuan NTU.

\section{B. Pengujian dan Analisa RTC DS1307}

Pengujian RTC disini bertujuan untuk mengetahui apakah RTC mampu menjadi pewaktu seperti halnya jam analog ataupun jam digital. Pada pengujian kali ini dilakukan perbandingan jam yang ditampilkan oleh RTC dan jam yang ditampilkan oleh jam digital yang dapat dilihat pada gambar 7 .

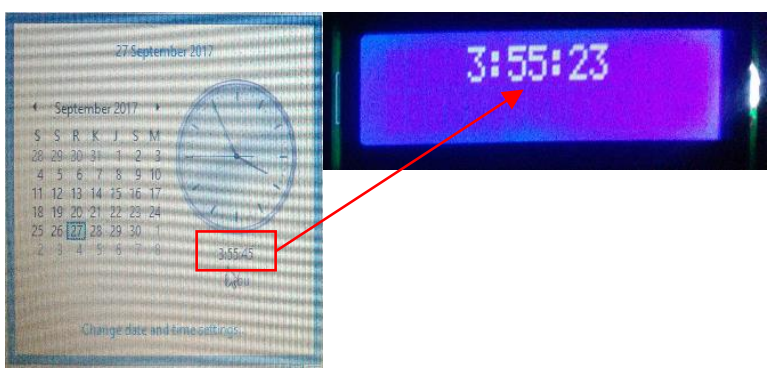

Gambar 7. Pengujian waktu pada RTC

Dari data diatas dapat disimpulkan bahwa pewaktuan RTC yang dirancang sudah sesuai dengan waktu yang sebenarnya dan dapat digunakan sebagaiamana halnya jam digital. RTC nantinya akan menjadi penentu waktu pemberian makan ikan setiap pagi dan sore. Wakru RTC diatur dimana waktunya akan selalu update setiap saat. Pada modul RTC terdapat sebuah batrai yang fungsinya untuk mensuplai modul agar waktunya selalu update walaupun tidak mendapat suplai dari mikrokontroler. Dari hasil pengujian waktu yang didapat dari waktu RTC dengan waktu yang didapat dari komputer hampir sama keduanya, hanya berbeda 22 detik dari jam yang ada pada laptop. Hasil pengujian ini dapat dilihat tidak ada perbedaan waktu yang terlalu jauh dengan waktu yang sebenarnya. Dengan begitu pemanfaatan RTC ini dapat digunakan sebagai waktu pemberian makan ikan real dengan waktu yang sebenarnya. Pada alat ini RTC akan menjadi pengatur pemberian makan ikan yang terjadwal yang akan bekerja sesuai table 5 .
Tabel 5 Jadwal makan lele

\begin{tabular}{cc}
\hline Jam & Servo \\
\hline $7: 00: 00$ & $60^{\circ}$ \\
\hline $7: 00: 01$ & $-60^{\circ}$ \\
\hline $19: 00: 00$ & $60^{\circ}$ \\
\hline $19: 00: 01$ & $-60^{\circ}$ \\
\hline
\end{tabular}

\section{Pengujian dan Analisa Sensor HC-SRO4}

Pengujian sensor ini bertujuan untuk mengetahui keakuratan sensor HC-SR04 dengan jarak sebenarnya. Pengujian dilakukan dengan cara membuat listing program. Kemudian membandingkan data pembacaan sensor dengan menggunakan alat ukur, yaitu menggunakan penggaris.Untuk menentukan persentase kesalahan dan dapat dihitung dengan rumus sebagai berikut dan dapat dilihat pada table 6 hasil pengukuran serta persentase kesalahan yang didapat :

$\frac{\text { Jarak pembacaan sensor - jarak sebenarnya }}{\text { jarak pembacan sensor }} \times 100 \%$

Tabel 6. Hasil pengukuran sensor HC-SR04

\begin{tabular}{cccccc}
\hline & \multirow{2}{*}{$\begin{array}{c}\text { Jarak } \\
\text { No. }\end{array}$} & $\begin{array}{c}\text { Jarak } \\
\text { sebenarnya }\end{array}$ & $\begin{array}{c}\text { sensor } \\
\end{array}$ & Tegangan sensor & \\
& 1 & 3 & $3 \mathrm{mV}$ & $5 \mathrm{Mv}$ & $66,6 \%$ \\
\hline 1 & 2 & 3 & $3 \mathrm{mV}$ & $5 \mathrm{mV}$ & $50 \%$ \\
\hline 2 & 3 & 3 & $3 \mathrm{mV}$ & $5 \mathrm{mV}$ & $0 \%$ \\
\hline 3 & 4 & 4 & $3 \mathrm{mV}$ & $5 \mathrm{mV}$ & $0 \%$ \\
\hline 4 & 5 & 5 & $3 \mathrm{mV}$ & $7 \mathrm{mV}$ & $0 \%$ \\
\hline 5 & 10 & 10 & $3 \mathrm{mV}$ & $15 \mathrm{mV}$ & $0 \%$ \\
\hline 6 & 15 & 15 & $3 \mathrm{mV}$ & $24 \mathrm{mV}$ & $0 \%$ \\
\hline 7 & 20 & 20 & $3 \mathrm{mV}$ & $32 \mathrm{mV}$ & $0 \%$ \\
\hline 8 & 25 & 25 & $3 \mathrm{mV}$ & $40 \mathrm{mV}$ & $0 \%$ \\
\hline 9 & 30 & 30 & $3 \mathrm{mV}$ & $50 \mathrm{mV}$ & $0 \%$ \\
\hline 10 & & & & & \\
\hline
\end{tabular}

Pengukuran dilakuan dari $1 \mathrm{~cm}$ sampai $30 \mathrm{~cm}$. Jarak antara $0 \mathrm{~cm}$ sampai $2 \mathrm{~cm}$ terjadi error. Sensor HC-SR04 memiliki spesifikasi dapat membaca jarak benda dari 2 - $350 \mathrm{~cm}$. Pada tabel 12 pengukuran pada jarak $2 \mathrm{~cm}$ masih mengalami error dimana pengukuran yang terbaca oleh sesor adalah $3 \mathrm{~cm}$. Setelah melakukan pengujian maka didapatkan hasil pengujian sensor Ultrasonic HC-SR04 pada tabel 12 perbedaan yang terjadi pada saat pembacaan data ketinggian dibawah $3 \mathrm{~cm}$, persentase kesalahan mencapai $66,6 \%$. Kesalahan ini terjadi karena batas minimum pembacaan data sensor adalah $2 \mathrm{~cm}$, pada saat pengujian jarak dari $3 \mathrm{~cm}$ sampai jarak $30 \mathrm{~cm}$ jarak pengujian antara sensor dengan jarak yang yang sebenarnya kesalahannya yaitu $0 \%$. Ketika melakukan pengukuran transmitter (pemancar) akan memancarkan gelombang ultrasonik pada suatu benda yang ada didepan sensor kemudian pantulan gelombang ultrasonik dari benda di depan sensor akan diterima oleh receiver (penerima). Setelah proses tersebut baru didapatkan jarak antara sensor dengan benda. Dari tabel 12 dapat dilihat tegangan pada pin trigger selalu tetap walaupun jarak yang berbeda- 
beda. Beda halnya dengan tegangan pada pin echo, tegangan pada pin echo selalu berubah-rubah seiring perubahan jarak. Makin jauh jarak yang diukurmaka makin besar juga tegangan pada pin echo. Sinyal ultrasonik yang dipancarkan transmitter dan yang diterima oleh receiver berupa sinyal kotak (pulsa). Sinyal yang diterima oleh receiver akan menjadi data input jarak pada mikrokontroler.Sensor ultrasonic menghitung jarak dengan cara menghitung waktu saat sinyal yang di pancarkan oleh pemancar (trigger) diterima kembali oleh receiver (echo), kemudian waktu tersebut di konversi menjadi jarak.Untuk mengkonversi dari waktu ke jarak digunakan rumus :

$$
s=v x(t / 2)
$$

Dimana, s (cm): Jarak ( $\mathrm{cm}), \mathrm{t}(\mu \mathrm{s})$ : waktu sinyal dari transmitter diterima oleh receiver, $\mathrm{v}(\mathrm{cm} / \mu \mathrm{s}): 348,3$ $\mathrm{m} / \mathrm{s}=0.03483 \mathrm{~cm} / \mu \mathrm{s}$. Karena waktu yang terbaca adalah lama sinyal dari transmitter menuju ke permukaan benda kemudian kembali ke receiver maka pada rumus waktu dibagi 2. Jarak yang terbaca oleh sensor ultrasonik adalah jarak antara sensor dengan permukaan air, jadi untuk mendapatkan ketinggian air di dalam akuarium penulis menggunakan cara di bawah ini :

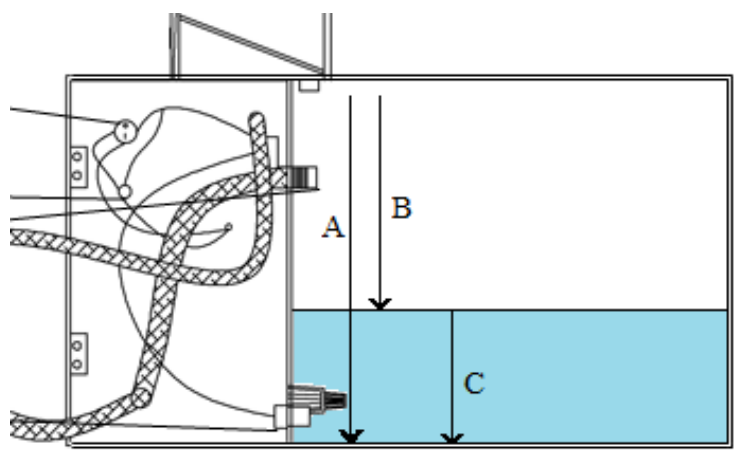

Gambar 8. Pengukuran ketinggian air

Gambar 8 menampilkan pemasangan sensor ultrasonik HC-SR04 pada akuarium. Berdasarkan gambar diatas maka untuk menentukan ketinggian air akuarium dapat menggunakan rumus sederhana :

$$
C=A-B
$$

Dimana $C$ adalah Ketinggian air di dalam akuarium, dan AJarak antara sensor ultrasonik dengan dasar akuarium ( $23 \mathrm{~cm}$ ), sedangkan $B J a r a k$ yang terbaca oleh sensor ultrasonik

Ketika keadaan minimum jarak yang terbaca oleh sensor yaitu $18 \mathrm{~cm}$ sehingga tinggi air akuarium yaitu : $\mathrm{C}=\mathrm{A}-\mathrm{B}$

$$
\mathrm{C} \quad=23-18 \mathrm{~cm}=5 \mathrm{~cm}
$$

Ketika keadaan maksimum jarak yang terbaca oleh sensor yaitu $8 \mathrm{~cm}$ sehingga tinggi air akuarium adalah :

$\mathrm{C}=\mathrm{A}-\mathrm{B}$

$\mathrm{C}=23-8$

$\mathrm{C}=15 \mathrm{~cm}$
Perbedaan pembacaan tinggi air yang terbaca oleh sensor dengan tinggi air menggunakan alat ukur di sebabkan oleh riak pada permukaan air.

\section{Pengujian dan Analisa Rangkaian Motor Servo}

Pengukuran tegangan pada motor servo yang dilakukan pada titik-titik pengukuran yang telah ditentukan. Pengujian rangkaian servo ini dilakukan dari sudut 150 sampai dengan sudut 900 . Tujuan pengujian dilakukan untuk melihat sudut berapa yang cocok digunakan untuk membuka katup tempat pakan ikan ketika memberi makan ikan. Tabel 7 adalah pengukuran tegangan dari pengujian servo.

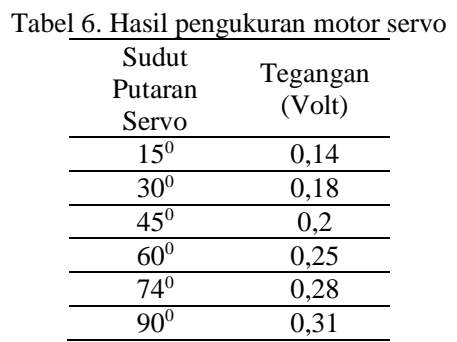

Dilihat dari hasil pengukuran tegangan servo, tegangan yang terukur pada servo berubah-ubah seiring sudut putaran servo. Semakin besar sudut putaran servo maka semakin besar juga tegangan yang dibutuhkan untuk sudut putaran servo. Sudut putaran servo dan lama servo terbuka dapat mengatur banyak takaran pakan ikan yang diberikan pada saat pemberian makan. Sudut putaran servo yang dibutuhkan untuk memberi makan ikan adalah 600 dengan lama terbukanya adalah 0.5 detik. Selama terbukanya katup tempat pakan ikan, pakan ikan yang dikeluarkan sebanyak 10 gram dalam sekali pemberian pakan ikan.

\section{E. Pengujian dan Analisa Rangkaian Relay}

Relay digunakan untuk pengaktifan pompa dan solenoid. Ketika relay diaktifkan maka pompa akan aktif dan begitupun sebaliknya. Aktifnya relay tergantung dari data yang dibaca oleh sensor turbidity. Jika nilai kekeruhan kolam ikan $<700$ maka relay aktif dengan saat bersamaan pompa air aktif. Berikut titik pengukuran yang dapat dilihat pada gambar 9

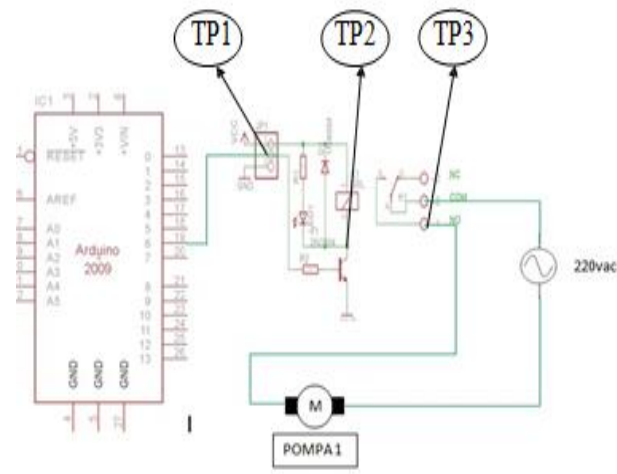

Gambar 9 . Titik pengukuran rangkaian relay 
Berdasarkan hasil dari pengukuran pada titik pengukuran sesuai dengan gambar 9 dapat dilihat pada tabel 7 adalah sebagai berikut.

Tabel 7. Hasil pengukuran transistor rangkaian relay

\begin{tabular}{|c|c|c|c|c|c|}
\hline $\begin{array}{c}\text { Sensor GE } \\
\text { Turbidity }\end{array}$ & $\begin{array}{c}\text { Kondisi } \\
\text { Picu }\end{array}$ & TP1 & TP2 & Pompa 1 & $1 \begin{array}{c}\text { Keteran } \\
\text { gan }\end{array}$ \\
\hline $\begin{array}{c}\mathrm{ADC}<=940 \\
\& \\
\mathrm{ADC}>=700\end{array}$ & HIGH & $0 \mathrm{Vdc}$ & $5 \mathrm{Vdc} 0 \mathrm{Vac}$ & - Mati & $\begin{array}{l}\text { Volume } \\
\text { Air tetap }\end{array}$ \\
\hline
\end{tabular}

$\begin{gathered}\text { ADC }>940 \\ \& \\ \text { ADC }<700\end{gathered}$
LOW

Rangkaian relay dirancang dengan memanfaatkan transistor sebagai saklar. Apabila transistor diberi tegangan $5 \mathrm{Vdc}$ dengan logika high, maka akan membuat transistor bekerja. Transistor akan bekerja apabila tegangan pada VBE telah mencapai tegangan kerja transistor 0.83 Volt. Ketika transistor bekerja maka anak kontak relay akan mengaktifkan pompa air dan solenoid.Pada transistor bekerja sebagai saklar yang ditandai dengan tegangan yang dihasilkan pada VCE, jika tegangan VCE = Vcc maka tegangan tersebut berada dalam keadaan Cut Off. Sedangkan jika VCE < VCC. Maka tegangan tersebut berada dalam saturasi.

\section{IV.KESIMPULAN}

Berdasarkan hasil pembuatan alat, pengujian dan Analisa alat, maka dapat diambil kesimpulan

1. Ikan lele dapat berkembang dengan baik dalam keadaan air yang bersih dan pertumbuhan akan terhambat dalam keadaan air kotor, yang mana tingkat kebersihan telah ditentukan.

2. Sensor GE Turbidity telah bekerja dengan sebagai mana mestinya, dimana pada saat keadaan air jernih sensor GE Turbidity didapatkan data ADC 960 , pada saat kotor data ADC 699.

3. Sensor ultrasonic bekerja untuk mengukur ketinggian air dan pakan ikan yang mana pada sensor ultrasonic kolam berguna untuk mengatur tinggi minimal dan maksimal air kolam, sama dengan sensor ultrasonic pada pakan ikan dengan output buzzer.

4. Air akan berganti secara otomatis saat data ADC sensor turbidity kecil sama dari 700, katup solenoid akan terbuka untuk membuang air kotor dari dalam akuarium hingga batas minimum ( $5 \mathrm{~cm}$ ), kemudian katup akan tertutup dan selenoid akan hidup untuk memasukan air bersih kedalam akuarium hinnga batas maksimum $(15 \mathrm{~cm})$.

5. Alat pemberian makan ikan dapat memberi makan ikan secara terjadwal pada waktu 07.00 dan 19.00 setiap harinya. Dalam satu kali pemberian makan ikan, jumlah pakan ikan yang diberikan sebanyak 10 gram.

\section{REFERENSI}

[1] W Yeqin. Direct Drive Electrohydraulic Servo Control System Design with SelfTuning Fuzzy PID Controller. TELKOMNIKA (Telecommunication Computing Electronics and Control). 2013; 11(6): 3374-3382.

[2] C Xian-gang, Z Jian-bin. Servo Motor Decoupling Control Based on PI Fuzzy Adaptive Method. TELKOMNIKA (Telecommunication Computing Electronics and Control). 2013; 11(5): 2612-1618.

[3] W Yeqin. Direct Drive Electrohydraulic Servo Control System Design with SelfTuning Fuzzy PID Controller. TELKOMNIKA (Telecommunication Computing Electronics and Control). 2013; 11(6): 3374-3382.

[4] YK Lu. Adaptive Fuzzy Integral Sliding Mode Regulator for Induction Motor Using Nonlinear Sliding Surface. IJPEDS International Journal of Power Electronics and Drive Systems. 2015; 5(4): 512-519.

[5] Prerana ; Mangalpady R. Shenoy ; Bishnu P. Pal ; Banshi D. Gupta. Design, Analysis, and Realization of a Turbidity Sensor Based on Collection of Scattered Light by a FiberOptic Probe. IEEE Sensors Journal ( Volume: 12 , Issue: 1, Jan. 2012 ) Page(s): $44-50$

[6] Mohamad Azrulamin Adzuan, Mohd Hezri Fazalul Rahiman , Ahmad Aftas Azman. Design and development of infrared turbidity sensor for Aluminium Sulfate coagulant process. 2017 IEEE 8th Control and System Graduate Research Colloquium (ICSGRC). Malaysia

[7] Azmar. Fahmi. 2012. "Pengendalian Kekeruhan Air Pada Akuarium Dengan Tampilan Output Suara", Politeknik Negeri Padang

\section{[8] PERMENKES RI No.416 Tahun 1990.}

[9] Procedings Seminar Nasional Teknik Elektro (FORTEI 2016)ISBN 978-979-097-420-3 Departemen Teknik Elektro UNDIP.

[10] Ilham Ananda. 2017. "Pengontrolan Penyaring dan penggantian Air Akuarium Secara Otomatis Berbasis Mikrokontroler”. Politeknik Negeri Padang. 